\title{
Perspective
}

PERSPECTIVE Actualité en histoire de l'art

Comptes rendus | 2010

\section{Mary Beard, The Parthenon, Cambridge, Harvard University Press, 2010}

\section{Zeynep Çelik}

\section{OpenEdition}

Journals

Édition électronique

URL : http://journals.openedition.org/perspective/2630

DOI : 10.4000/perspective.2630

ISSN : 2269-7721

Éditeur

Institut national d'histoire de l'art

Référence électronique

Zeynep Çelik, « Mary Beard, The Parthenon, Cambridge, Harvard University Press, 2010 », Perspective [En ligne], Comptes rendus, mis en ligne le 01 août 2013, consulté le 01 octobre 2020. URL : http:// journals.openedition.org/perspective/2630 ; DOI : https://doi.org/10.4000/perspective.2630

Ce document a été généré automatiquement le 1 octobre 2020. 


\section{Mary Beard, The Parthenon, Cambridge, Harvard University Press, 2010}

Zeynep Çelik

RÉFÉRENCE

Mary Beard, The Parthenon, Cambridge, Harvard University Press, 2010. 
1 À la lumière de récents débats concernant les antiquités, notamment avec la réouverture du Musée de l'Acropole à Athènes, cette édition révisée de l'ouvrage de Mary Beard sur le Parthénon paru en 2002 se montre encore plus percutante que l'originale. Destiné à un large public, y compris des touristes, l'ouvrage livre un panorama fascinant qui englobe architecture, archéologie, histoire culturelle, contextes politiques changeants et la construction de mythes. Partant des histoires anciennes de l'édifice et des controverses soulevées par les marbres d'Elgin, Beard arrive à l'époque actuelle, présentée finalement comme un épisode de plus dans des débats qui ne cessent de questionner le monument, ses significations et son avenir. L'humour et la clarté avec

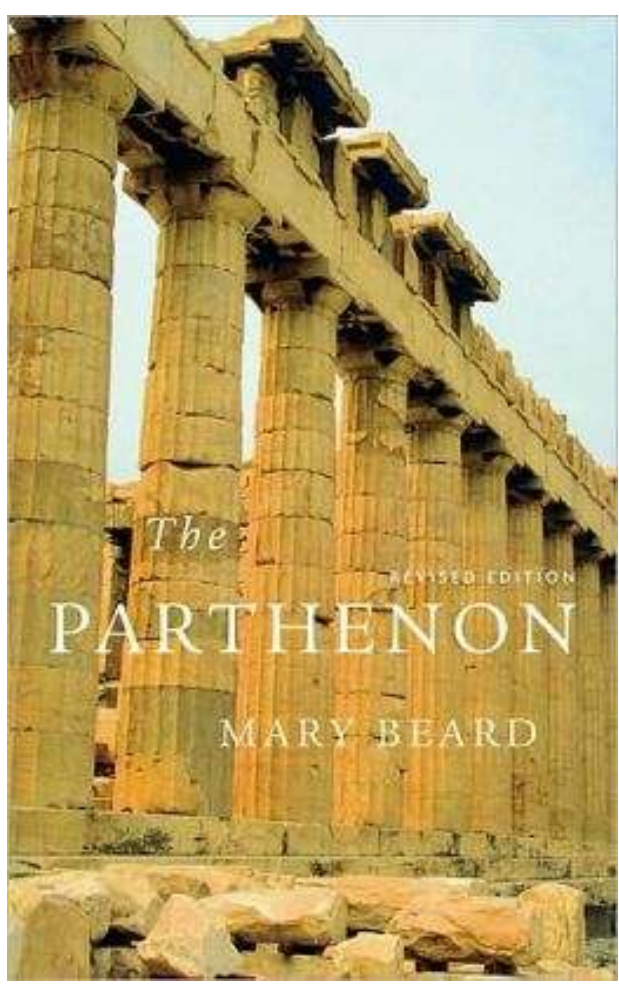
lesquelles l'auteur expose ses arguments puissants, ainsi que l'utilité des dessins, le choix judicieux des photographies et les notes pratiques pour le visiteur en font une monographie unique. 